\title{
Study of continuous lead removal from aqueous solutions by marble wastes: efficiencies and mechanisms
}

\author{
A. Mlayah $\cdot$ S. Jellali
}

Received: 15 February 2014/Revised: 21 October 2014/ Accepted: 10 November 2014/Published online: 25 November 2014 (C) Islamic Azad University (IAU) 2014

\begin{abstract}
Lead removal from synthetic solutions and real wastewater by Bianco Gioia marble wastes as abundant, renewable and eco-friendly materials was studied under different experimental conditions in a continuous stirring tank reactor. These marble wastes were found to be very efficient in removing lead for several experimental situations. Indeed, for initial aqueous $\mathrm{pH}$ values higher than 3.6, a lead removal efficiency of about $100 \%$ was achieved even for high aqueous concentrations $\left(200 \mathrm{mg} \mathrm{L}^{-1}\right)$, important feeding flow rates $\left(60 \mathrm{~mL} \mathrm{~min}^{-1}\right)$ and low marble waste dosage $\left(2 \mathrm{~g} \mathrm{~L}^{-1}\right)$. The best removal capacity $\left(175.7 \mathrm{mg} \mathrm{g}^{-1}\right)$ was obtained for an initial lead concentration of $200 \mathrm{mg} \mathrm{L}^{-1}$, a marble waste dose of $5 \mathrm{~g} \mathrm{~L}^{-1}$ and an aqueous $\mathrm{pH}$ of 5 . Even using the real wastewater with low aqueous $\mathrm{pH}$ (1.1), lead was also completely removed using $20 \mathrm{~g} \mathrm{~L}^{-1}$ of the tested marble wastes. According to the energy-dispersive spectroscopy and X-ray diffraction analyses, lead removal seems to be controlled by both precipitation as cerussite $\left(\mathrm{PbCO}_{3}\right)$ and hydrocerussite $\left(\mathrm{Pb}_{3}\left(\mathrm{CO}_{3}\right)_{2}(\mathrm{OH})_{2}\right)$, and adsorption onto the surface particles through cation exchange and complexation. The proposed low-cost material efficiently removes lead present in synthetic solutions and real wastewaters and constitutes an interesting environmental management option.
\end{abstract}

Keywords Dynamic mode - Mineral adsorbents . Precipitation · Wastes management $\cdot$ Water pollutants

\footnotetext{
A. Mlayah

Geo-resources Laboratory, Water Research and Technologies Centre (CERTE), BP 273, 8020 Soliman, Tunisia

S. Jellali $(\bowtie)$

Wastewater Treatment Laboratory, Water Research and Technologies Centre (CERTE), BP 273, 8020 Soliman, Tunisia e-mail: salah.jallali@ certe.rnrt.tn
}

\section{Introduction}

Water resource pollution by heavy metals is considered as a serious environmental problem due to their toxic effects in water bodies (Cechinel et al. 2013). Lead, which is discharged in wastewaters from many industrial processes such as the manufactories of batteries, paint coatings, glass and dyes, is potentially toxic for both humans and the aquatic environment (Banerjee 2014). Indeed, even at low concentrations, lead can seriously damage the human liver, kidney, reproductive and nervous systems and also causes the poisoning of aquatic organisms and severe changes in the aquatic fauna and flora (Singh et al. 2014). Moreover, lead is non-biodegradable and tends to be highly accumulated by organisms as part of the food chain (Blazquez et al. 2010). In this context, the maximum lead concentration in the discharged wastewaters into receiving bodies allowed by Tunisian legislation is fixed to $0.1 \mathrm{mg} \mathrm{L}^{-1}$ and according to the USEPA standards, the current limit for drinking water is $0.015 \mathrm{mg} \mathrm{L}^{-1}$ (Momcilovic et al. 2011).

During the last decades, various technologies have been applied for heavy metal removal from industrial wastewaters with different degree of efficiency such as chemical precipitation, ion exchange, reverse osmosis and membrane filtration. However, these methods require considerable capital investment and maintenance costs for infrastructure and reagents. Adsorption onto natural materials is currently considered as an emerging and attractive technology because of its effectiveness and economy in heavy metals removal from wastewaters. Different raw and modified organic natural materials have been tested for heavy metals removal from aqueous solutions such as raw alga Anabaena sphaerica biomass (Abdel-Aty et al. 2013), raw Peganum harmala seeds (Zamani et al. 2013), modified Symphoricarpus albus 
biomass (Akar et al. 2012), modified olive tree pruning (Calero et al. 2013) and activated carbon from apple pulp (Depci et al. 2012). The main involved mechanisms were cation exchange and complexation with the active groups of the biomasses' constituents. Furthermore, the efficiency of some raw and modified inorganic materials for lead removal from aqueous solutions has been tested, such as natural zeolite (Calvo et al. 2009); raw illitic clays (Ozdes et al. 2011), palygorskite (Fan et al. 2009; Sheikhhosseini et al. 2013); sepiolite (Sheikhhosseini et al. 2013), dolomite (Irani et al. 2011), ore mine tailings wastes (Venalainen 2012), natural Greek bentonites (Bourliva et al. 2013) and modified attapulgite (Deng et al. 2013). The suggested corresponding mechanisms were adsorption by complex formation with hydroxyl groups as well as cation exchange. Calcite, which is the crystalline form of $\mathrm{CaCO}_{3}$, has been also tested for heavy metals removal from aqueous solutions under static conditions (Chada et al. 2005; Ghazy and Ragab 2007; Ghazy and Gad, 2010; Rangel-Porras et al. 2010; Godelitsas et al. 2003). For example, Ghazy and Gad (2010) tested the use of Egyptian powdered marble wastes mainly formed by calcite and dolomite for lead removal from synthetic aqueous solutions in batch mode. They proved that this material is very efficient in removing lead under large experimental conditions with a maximum monolayer adsorption capacity of $101.6 \mathrm{mg} \mathrm{g}^{-1}$. Although calcite materials have demonstrated a relatively high capacity for retention of some metals, the involved mechanisms and the surface process involved have not been explored in detail. Moreover, these removal capacities were evaluated under static flow conditions (batch mode), which are usually limited to the treatment of small quantities of synthetic solutions and present large difficulties for up scaling tasks. In order to find a solution to this problem, the application of dynamic-flow set ups (such as continuous stirring tank reactors (CSTRs)) can be considered as a good alternative. In fact, only few studies have focused on this approach regarding phosphorus removal from aqueous solutions by using powdered marble wastes (Jaouadi et al. 2014a) and acid mine drainage (Wei et al. 2008).

Therefore, the main purposes of the current study were (1) to evaluate lead removal efficiencies from synthetic aqueous solutions and real wastewater by abundant, renewable and eco-friendly calcitic materials (Bianco Gioia marble wastes (BGMW) in CSTR system) and (2) to assess the involved mechanisms through specific assays and analyses.

This research work has been performed at the Water Research and Technologies Centre (CERTE), Tunisia during 2012-2013.

\section{Materials and methods}

BGMW preparation and characterization

Marble wastes are freely available with relatively huge amounts in several countries. Indeed, around $70 \%$ of this mineral resource is wasted in the mining, processing and polishing procedures (Aukour and Al-Qinna 2008). These wastes are always discharged into empty pits or landfills without any reuse. In this study, the used marble wastes were generated from the manufacturing of large stones of "Bianco Gioia" marble (BGMW) imported from Italy. They were collected, free of charge, as a dry powder at the vicinity of the cutting and polishing devices from a private marble processing workshop located in Borj Cedria city, which is situated at about $25 \mathrm{~km}$ at the south of Tunis, Tunisia. In this study, BGMW was sieved mechanically using a sieve with a mean diameter of $2 \mathrm{~mm}$ in order to remove any existing fragments. Then, it was washed with distilled water and dried in an oven at $40{ }^{\circ} \mathrm{C}$ for $48 \mathrm{~h}$ to a constant weight. The adsorbent characterization including the particle size distribution, the mineralogical analysis, the chemical composition and the $\mathrm{pH}$ of zero point charge was determined as indicated by Jaouadi et al. (2014b). They indicated that BGMW were constituted by fine solid particles with a mean diameter of about $22.6 \mu \mathrm{m}$. Furthermore, they were mainly formed by calcite with relatively high contents of calcium. Their $\mathrm{pH}_{\mathrm{ZPC}}$ and BET were determined to 8.11 and $0.14 \mathrm{~m}^{2} \mathrm{~g}^{-1}$, respectively (Jaouadi et al. 2014b).

Preparation and analysis of synthetic lead solutions

Analytical grade of lead nitrate $\left(\mathrm{Pb}\left(\mathrm{NO}_{3}\right)_{2}\right)$ was used in CSTR tests as the source of lead ions. A stock lead solution of $1,000 \mathrm{mg} \mathrm{L}^{-1}$ was prepared with distilled water and used throughout this study. The analysis of lead concentrations at the outlet of the CSTR was performed using an atomic absorption spectrometer (Perkin Elmer AAnalyst 200). During the assays, the $\mathrm{pH}$ values were adjusted with $0.1 \mathrm{M} \mathrm{HNO}_{3}$ or $0.1 \mathrm{M} \mathrm{NaOH}$. The $\mathrm{pH}$ measurements were performed using a pH meter (692 pH/ion meter, Metrohm).

CSTR lead removal studies

\section{Laboratory CSTR presentation and experimental protocol}

Continuous flow tests were carried out by a CSTR system for the removal of lead from synthetic solutions and real industrial wastewater (Fig. 1). The contact between BGMW and lead dissolved in aqueous solutions was ensured in a 1.2-L glass reactor. At the beginning of the 
Fig. 1 Schematic representation of the CSTR used for the study of lead removal by BGMW

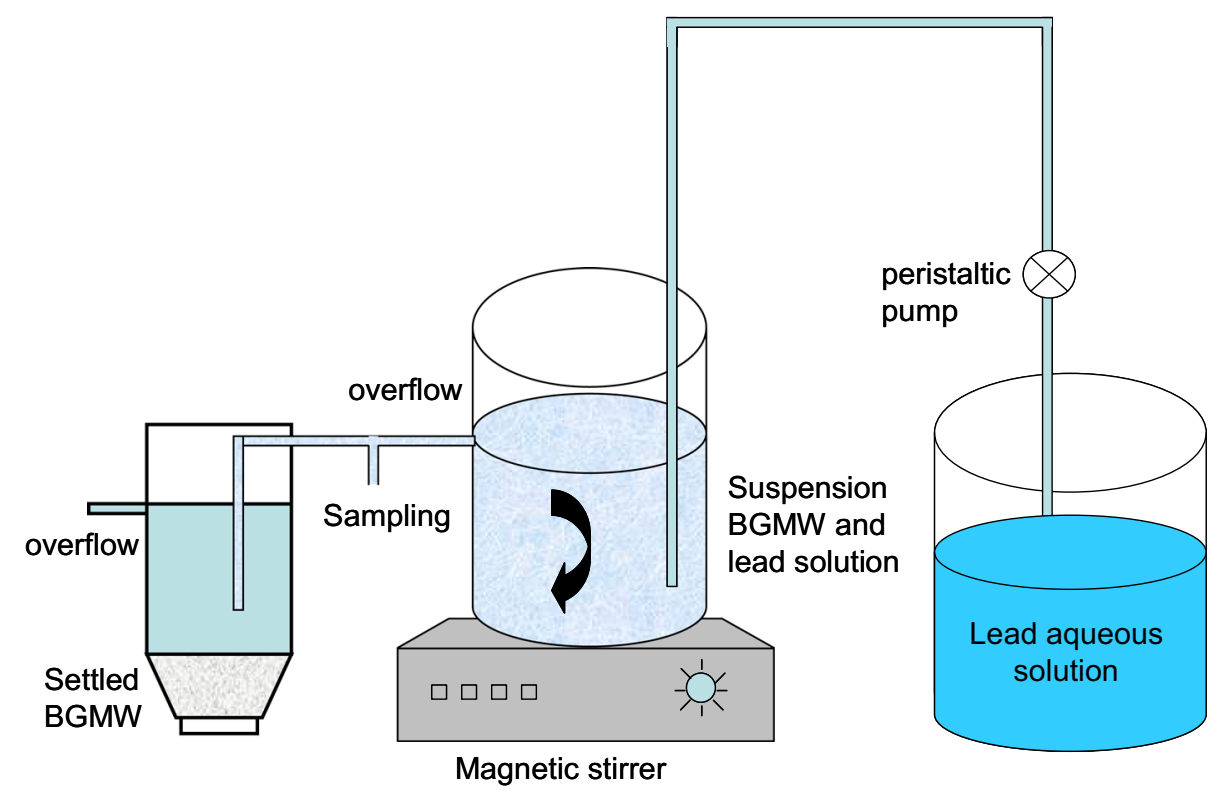

assays, the desired BGMW dosage was placed in the reactor, which is then rapidly filled with the aqueous lead solution at the desired concentration. Afterward, the leadcontaining water was continuously fed from a 20-L-volume tank to the CSTR system with a variable flow pump (Masterflex, Cole-Parmer Instrument Company, USA) at different flow rates corresponding to the chosen contact times. The reactor was continuously stirred at $300 \mathrm{rpm}$ using a magnetic stirrer (Agimafic-S, IP. Selecta Company) for several hours after reaching of the equilibrium. This state is characterized by a quasi stability of lead concentrations at the entrance of the settling setup.

The effluent was sampled at the entrance of the settling device at certain time intervals to determine the efficiency of this CSTR system for the removal of lead. For each aqueous sample $(10 \mathrm{~mL})$, the suspension (containing water and BGMW particles) was filtered through filter paper and then the filtrate was analyzed in order to determine its dissolved lead concentration. All assays, presented hereafter, were conducted in duplicate, and the mean values were reported.

\section{Effect of influent lead concentration}

The effect of influent lead concentration on its removal by BGMW was investigated using four synthetic concentrations 50, 100, 150 and $200 \mathrm{mg} \mathrm{L}^{-1}$. This concentrations range was tested in order to determine the BGMW capacity regarding lead removal for other highly concentrated industrial wastewaters, where the related concentrations could reach 200-500 $\mathrm{mg} \mathrm{L}^{-1}$ (Akar et al. 2012). The aqueous $\mathrm{pH}$, BGMW dosage and flow rate were fixed to 3.6, $5 \mathrm{~g} \mathrm{~L}^{-1}$ and $20 \mathrm{~mL} \mathrm{~min}^{-1}$, respectively.

\section{Effect of the BGMW dosage}

The impact of BGMW dosage onto lead removal was explored at a constant $\mathrm{pH}$ influent, concentration of synthetic solution and feeding flow rate of $3.6,100 \mathrm{mg} \mathrm{L}^{-1}$ and $5 \mathrm{~g} \mathrm{~L}^{-1}$, respectively. The tested BGMW dosages were fixed to $1,2,3$ and $5 \mathrm{~g} \mathrm{~L}^{-1}$.

\section{Effect of the influent feeding flow rate}

The effect of the contact time between BGMW particles and the lead synthetic solutions was determined for fixed feeding concentration, $\mathrm{pH}$ and BGMW dosage of $100 \mathrm{mg} \mathrm{L}^{-1}, 3.6$ and $5 \mathrm{~g} \mathrm{~L}^{-1}$, respectively. The tested flow rates were maintained constants at 20, 40 and $60 \mathrm{~mL} \mathrm{~min}{ }^{-1}$ using the peristaltic pump. These flow rates correspond to theoretical hydraulic residence times in the reactor of 60,30 and $20 \mathrm{~min}$, respectively.

\section{Effect of initial aqueous $p H$}

The effect of initial aqueous $\mathrm{pH}$ on lead removal has been investigated for a synthetic solution feeding concentration, initial BGMW dosage and continuous feeding flow rate of $100 \mathrm{mg} \mathrm{L}^{-1}, 5 \mathrm{~g} \mathrm{~L}^{-1}$ and $20 \mathrm{~mL} \mathrm{~min}^{-1}$, respectively. The tested initial $\mathrm{pH}$ values were fixed to 2 , 3.6 and 5. Above pH 5, lead removal studies were not performed due to the possible precipitation of lead in the form of $\mathrm{Pb}(\mathrm{OH})_{2}$ (Blazquez et al. 2010; Rangel-Porras et al. 2010). 


\section{Effect of ions competition}

In order to assess the competing effect of the presence of other cations on lead removal by BGMW, a CSTR removal test of lead (50 $\mathrm{mg} \mathrm{L}^{-1}$ ) was performed following specific aqueous concentrations of some ions such as cadmium (10 $\left.\mathrm{mg} \mathrm{L}^{-1}\right)$, copper $\left(10 \mathrm{mg} \mathrm{L}^{-1}\right)$ and zinc $\left(30 \mathrm{mg} \mathrm{L}^{-1}\right)$. These concentrations were chosen on the basis of a previous study related to heavy metals repartition in Tunisian mines (Mlayah et al. 2009). Moreover, the BMGW dosage, aqueous $\mathrm{pH}$ and feeding flow rate were fixed to $5 \mathrm{~g} \mathrm{~L}^{-1}$, 3.6 and $20 \mathrm{~mL} \mathrm{~min}^{-1}$, respectively.

\section{Validation with industrial wastewater}

Industrial wastewater effluent from a battery manufacture in Grombalia city (North East of Tunisia) was used to study the effectiveness of the continuous flow system in treating real wastewater. This wastewater is a very acidic effluent with an average $\mathrm{pH}$ of 1.1 and has relatively high contents of lead and sulfates (Table 1). Three BGMW dosages were tested: 5, 10 and $20 \mathrm{~g} \mathrm{~L}^{-1}$ at a constant flow rate of $20 \mathrm{~mL} \mathrm{~min}^{-1}$.

\section{Lead removal parameters calculation}

The lead removal by BGMW at equilibrium, $q_{\mathrm{e}}$ (mg removed lead $\mathrm{g}^{-1}$ BGMW), was calculated from mass balance equation as follows (Jaouadi et al. 2014a):

Table 1 Main chemical composition of the used real wastewater

\begin{tabular}{lll}
\hline Parameter & $\begin{array}{l}\text { Concentration } \\
(\mathrm{mg} / \mathrm{L})\end{array}$ & $\begin{array}{l}\text { Tunisian discharging norm } \\
(\mathrm{mg} / \mathrm{L})\end{array}$ \\
\hline Suspended solids & 76.5 & 30 \\
$\mathrm{pH}(-)$ & 1.1 & $6.5-8.5$ \\
Lead & 5.4 & 0.1 \\
Cadmium & 0.12 & 0.005 \\
Copper & 0.55 & 0.5 \\
Iron & 3.03 & 1 \\
Manganese & 0.69 & 0.5 \\
Nickel & 0.34 & 0.2 \\
Sodium & 320 & 500 \\
Potassium & 7.5 & 50 \\
Magnesium & 4.29 & 200 \\
Calcium & 666 & 500 \\
Chlorides & 667 & 600 \\
Sulfates & 9,360 & 600 \\
\hline
\end{tabular}

$q_{\mathrm{e}}=\frac{M_{t_{0}}+M_{\mathrm{inj}}-M_{t_{\mathrm{f}}}-M_{\text {recup }}}{M_{\mathrm{BGMW}}}$

where $t_{0}$ and $t_{\mathrm{f}}$ are the times corresponding to the start and the end of the experiment, respectively. $M_{t_{0}}, M_{\mathrm{inj}}, M_{t_{\mathrm{f}}}, M_{\text {recup }}$ and $M_{\mathrm{BGMW}}$ are the initial lead mass existing inside the reactor before the start of the experiment, the injected mass in the reactor between the times $t_{0}$ and $t_{\mathrm{f}}$, the existing mass inside the reactor at the end of the experiment, the recuperated mass at the outlet of the reactor during the same time period, and the used BGMW amount, respectively. These masses are calculated using the following equations:

$M_{t_{0}}=C_{0} V_{\mathrm{r}}$

$M_{\mathrm{inj}}=C_{0} Q\left(t_{\mathrm{f}}-t_{0}\right)$

$M_{t_{\mathrm{f}}}=C_{\mathrm{f}} V_{\mathrm{r}}$

$M_{\text {recup }}=\int_{0}^{V_{\text {tot }}} C(t) \mathrm{d} v$

where $C_{0}, C(t)$ and $C_{\mathrm{f}}$, are the aqueous lead concentration measured at the influent, at time $t$ and final time at the reactor outlet, respectively. $Q$ is the applied flow rate. $V_{\mathrm{r}}$ and $V_{\text {tot }}$ are the reactor volume and the total solution volume recuperated at the outlet of the reactor.

Equation 5 was approximated using the trapeze method by the formula presented hereafter (Jellali et al. 2010):

$M_{\text {recup }}=\frac{1}{2} \sum_{i=0}^{i=n}\left(C_{i+1}-C_{i}\right)\left(V_{i+1}-V_{i}\right)$

where $C_{i+1}, C_{i}$ and " $V_{i+1}, V_{i}$ " are the lead aqueous concentrations and "recuperated volume at the outlet of the reactor" at the instants $t_{i+1}$ and $t_{i}$, respectively.

The lead removal efficiency at equilibrium (ARE) is calculated from the relation:

$\operatorname{ARE}(\%)=\frac{\left(C_{0}-C_{\mathrm{eq}}\right)}{C_{0}} \times 100$

where $C_{\text {eq }}$ is the average measured lead concentration at the outlet of the reactor at the equilibrium state.

Lead removal mechanisms exploration

Energy-dispersive spectroscopy

Energy-dispersive spectroscopy (EDS) was used to analyze the chemical elemental composition of BGMW surface before and after lead removal by a Quanta-200-Fei apparatus. The used equipment is formed by three main components: an X-ray detector; a pulse processing circuitry, which determines the energy of the detected X-rays; and an 
analyzer equipment, which interprets the X-ray data and displays it on a computer screen.

\section{$X$-ray diffraction}

X-ray diffraction (XRD) was used to determine the main phases present in the raw BGMW and in the solid phase formed after contact between lead and aqueous filtered solution resulting from shaking of $1,000 \mathrm{~mL}$ of distilled water with $5 \mathrm{~g}$ of BGMW. These two crystalline phases were analyzed using an $\mathrm{X}$-ray diffractometer $\mathrm{CuK} \alpha$ radiation, PW 1710 Philips, and scans were conducted from $0^{\circ}$ to $70^{\circ}$ at a rate of $2^{\circ} \mathrm{min}^{-1}$.

\section{Replication of CSTR experiments}

Each CSTR removal experiment cited above was performed twice to obtain reproductive results with an average error lower than $5 \%$. In the case of deviation larger than $5 \%$, more assays were conducted. Thus, all the data, presented hereafter, are the average values of minimum two tests.

\section{Results and discussion}

\section{Dynamic experiments results}

Removal efficiency of pollutants of CSTR is generally characterized by breakthrough curves which are composed of three stages. The first stage concerns the effluent concentrations decrease; the second is dealing with the equilibrium state (characterized by a plateau of concentrations); and the third presents the effluent concentration increase. The time taken to reach the equilibrium state, the duration of this plateau and the shape of the concentration time/ volume profile are very important parameters in order to obtain the dynamical behavior of this kind of assays (Chakraborty et al. 2011).

\section{Effect of influent lead concentration}

The lead breakthrough curves show that BGMW is very efficient in lead removal from the synthetic solutions (Fig. 2). Indeed, even for a relatively high influent concentration $\left(200 \mathrm{mg} \mathrm{L}^{-1}\right)$, the equilibrium effluent lead contents measured at the outlet of the CSTR were lower than the detection limit of the used apparatus $\left(0.01 \mathrm{mg} \mathrm{L}^{-1}\right)$. Moreover, this equilibrium state that is characterized by a constant concentration at the outlet of the reactor has been reached very quickly: Only $1.5 \mathrm{~min}$ was sufficient for influent with concentrations of 50 and $100 \mathrm{mg} \mathrm{L}^{-1}$. For the higher used concentrations ( 150 and $200 \mathrm{mg} \mathrm{L}^{-1}$ ), a total removal of lead

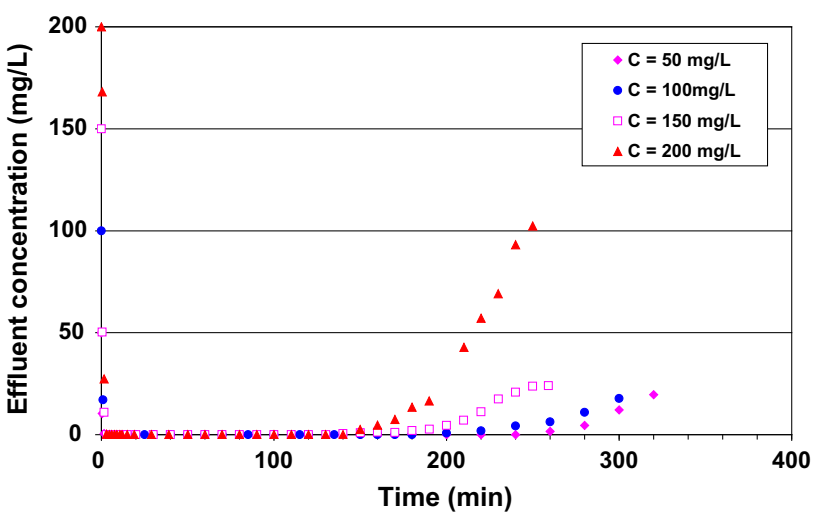

Fig. 2 Effect of influent aqueous concentrations on lead removal by BGMW (BGMW dosage $=5 \mathrm{~g} \mathrm{~L}^{-1}$, temperature $=20 \pm 2{ }^{\circ} \mathrm{C}$, flow rate $=20 \mathrm{~mL} \mathrm{~min}^{-1}$ and initial $\mathrm{pH}$ 3.6)

was obtained after only $3 \mathrm{~min}$ of the system operating (Fig. 2). This finding proves that BGMW can be considered as very attractive materials for lead removal from highly contaminated aqueous solutions. This relatively short-equilibrium time can be considered as a significant advantage for practical applications since the removal rate is extremely important for developing water treatment technology by low-cost materials. Relatively higher equilibrium times have been determined for several materials such as activated carbon from bovine bone (Cechinel et al. 2013), Symphoricarpus albus biomass (Akar et al. 2012) and modified attapulgite clay (Deng et al. 2013).

Furthermore, the breakthrough times after the equilibrium plateau concentrations $\left(C / C_{0}=1 \%\right)$ increased with decreasing the influent concentrations. Indeed, these experimental times were evaluated to 246, 204, 175 and $148 \mathrm{~min}$ for aqueous influent concentrations of 50, 100, 150 and $200 \mathrm{mg} \mathrm{L}^{-1}$, respectively (Fig. 2). This behavior is mainly due to the saturation of the active sorption sites of the used solid matrix particles and their continuous exit from the reactor (Jaouadi et al. 2014a). BGMW lead removal capacities increase with increasing the influent aqueous lead concentration. In fact, after $250 \mathrm{~min}$ of the beginning of the experiments, raising the influent lead concentration from 50 to 100,150 and $200 \mathrm{mg} \mathrm{L}^{-1}$ allows the BGMW to increase their removal capacities from 51.3, 101.5, 146.7 and $175.7 \mathrm{mg} \mathrm{g}^{-1}$, respectively. In this context, Cruz-Olivares et al. (2010) studied lead removal by de-oiled allspice husk (local Mexican lignocellulosic material) using glass laboratory columns (inside diameter of $1.78 \mathrm{~cm}$ and bed depth height of $15 \mathrm{~cm}$ ) for a feeding flow rate of $40 \mathrm{~mL} \mathrm{m^{-1 }}$ and initial lead concentrations ranging from 5 to $25 \mathrm{mg} \mathrm{L}^{-1}$ at $\mathrm{pH}$ of 5 . They showed that when the used initial concentration is higher, the time of column service is shorter, which is due to the rapidly saturation of their biosorbent. Furthermore, the sorption 
capacity of their biosorbent has tripled when the initial concentration increased from 5 to $25 \mathrm{mg} \mathrm{L}^{-1}$.

Thus, the increase in BGMW' efficiencies in removing lead could be attributed to the fact that higher is the influent concentration, higher is the concentration gradient between aqueous solution and the solid phase. Moreover, increasing initial aqueous lead concentration provides an important initial force to overcome pollutant mass transfer resistances between the aqueous and BGMW particles resulting in more important diffusion rates. Furthermore, for higher initial aqueous concentrations, the contact probability between lead ions contained in the aqueous phase and the
BGMW might be more privileged. Moreover, even at a fixed aqueous $\mathrm{pH}$ value, the precipitation of lead as $\mathrm{Pb}(\mathrm{OH})_{2}$ or $\mathrm{PbCO}_{3}$ should be favored with raising the initial aqueous concentrations since their solubility product were estimated to $1.2 \times 10^{-15}$ and $7.4 \times 10^{-14}$, respectively (Dong et al. 2010; McQuarrie et al. 2000).

In order to compare the BGMW efficiency among the common used materials to remove lead from aqueous solutions, a comparison based on the adsorbed amount was conducted with some mineral materials under dynamic conditions (Table 2). It appears clearly that BGMW could be considered as promising materials to remove lead.

Table 2 Comparison of lead removal by BGMW with other materials adsorbents under dynamic and static conditions

\begin{tabular}{|c|c|c|c|c|}
\hline Material & $\begin{array}{l}\text { Study } \\
\text { type }\end{array}$ & Experimental conditions & $\begin{array}{l}\text { Lead removal capacity } \\
(\mathrm{mg} / \mathrm{g})\end{array}$ & References \\
\hline Bianco Gioia marble wastes & CSTR & $\begin{array}{l}\text { Glass reactor: } 1.2 \mathrm{~L} ; \\
C_{0}=200 \mathrm{mg} \mathrm{L}^{-1} \\
\text { pH } 3.6 ; D=5 \mathrm{~g} \mathrm{~L}^{-1} ; \\
\text { flow rate }=20 \mathrm{~mL} \mathrm{~min}^{-1}\end{array}$ & 175.7 & This study \\
\hline Turkish clinoptilolite & Column & $\begin{array}{l}\text { Plexiglass column (height }=100 \mathrm{~cm} \text {; } \\
\text { diameter }=3 \mathrm{~cm} \text { ); } \\
\mathrm{M}=370 \mathrm{~g} ; C_{0}=50 \mathrm{mg} \mathrm{L}^{-1} \\
\mathrm{pH} 7.1 \text {; flow rate }=70 \mathrm{~mL} \mathrm{~min}^{-1}\end{array}$ & 7.97 & Turan et al. (2005) \\
\hline $\begin{array}{l}\text { Ecuadorianern heulandite } \\
\text { Ecuadorianern clinoptilolite }\end{array}$ & Column & $\begin{array}{l}\text { Glass column (height }=20 \mathrm{~cm} ; \\
\text { diameter }=2 \mathrm{~cm}) ; \\
\mathrm{M}=35 \mathrm{~g} ; C_{0}=428.9 \mathrm{mg} \mathrm{L}^{-1} ; \\
\mathrm{pH} 7-7.5 ; \text { flow rate }=1 \mathrm{~mL} \mathrm{~min}^{-1}\end{array}$ & $\begin{array}{l}8.6 \\
40.4\end{array}$ & Calvo et al. (2009) \\
\hline $\begin{array}{l}\text { Chemically modified Chinese } \\
\text { zeolite }\end{array}$ & Column & $\begin{array}{l}\text { Glass column (height }=30 \mathrm{~cm} \text {; } \\
\text { diameter }=1 \mathrm{~cm}) ; \\
\mathrm{M}=20 \mathrm{~g} ; C_{0}=261 \mathrm{mg} \mathrm{L}^{-1} ; \\
\text { pH 5; flow rate }=7.69 \mathrm{~mL} \mathrm{~min}^{-1}\end{array}$ & 75.21 & Han et al. (2006) \\
\hline Mexican soil & $\mathrm{Batch}^{\mathrm{a}}$ & $\begin{array}{l}C_{0}: 10-400 \mathrm{mg} \mathrm{L}^{-1} \\
D=5-10 \mathrm{~g} \mathrm{~L}^{-1} \\
\text { pH } 2-5.5\end{array}$ & $0.5-8$ & $\begin{array}{l}\text { Martinez-Villegas et al. } \\
\text { (2004) }\end{array}$ \\
\hline $\begin{array}{l}\text { Thai Kaolinite } \\
\text { Thai Illite }\end{array}$ & $\mathrm{Batch}^{\mathrm{a}}$ & $\begin{array}{l}C_{0}: 20-100 \mathrm{mg} \mathrm{L}^{-1} ; \\
D=20 \mathrm{~g} \mathrm{~L}^{-1} ; T=30^{\circ} \mathrm{C} .\end{array}$ & $\begin{array}{l}1.41 \\
4.29\end{array}$ & $\begin{array}{l}\text { Chantawong et al. } \\
\text { (2003) }\end{array}$ \\
\hline $\begin{array}{l}\text { Egyptian powdered marble } \\
\text { wastes }\end{array}$ & $\mathrm{Batch}^{\mathrm{a}}$ & $\begin{array}{l}C_{0}: 500-1,500 \mathrm{mg} \mathrm{L}^{-1} ; \\
D=1 \mathrm{~g} \mathrm{~L}^{-1} ; T=25^{\circ} \mathrm{C} ; \\
\text { pH } 7\end{array}$ & 101.6 & Ghazy and Gad (2010) \\
\hline Iranian perlite & $\mathrm{Batch}^{\mathrm{a}}$ & $C_{0}: 10-500 \mathrm{mg} \mathrm{L}^{-1}$ & 8.906 & Irani et al. (2011) \\
\hline Iranian dolomite & & $D=2 \mathrm{~g} \mathrm{~L}^{-1} ; T=25^{\circ} \mathrm{C}$ & 18.55 & \\
\hline Iranian diatomite & & $\mathrm{pH} 6$ & 24.21 & \\
\hline Turkish illitic clay & Batch $^{\mathrm{a}}$ & $\begin{array}{l}C_{0}: 50-1,200 \mathrm{mg} \mathrm{L}^{-1} \\
\mathrm{pH} 4 ; D=10 \mathrm{~g} \mathrm{~L}^{-1} \\
\text { room temperature }\end{array}$ & 53.76 & Ozdes et al. (2011) \\
\hline Chinese modified attapulgite & Batch $^{\mathrm{a}}$ & $\begin{array}{l}C_{0}: 4-100 \mathrm{mg} \mathrm{L}^{-1} ; \\
D=1.2 \mathrm{~g} \mathrm{~L}^{-1} ; \\
T=30^{\circ} \mathrm{C} ; \mathrm{pH} 5-5.3\end{array}$ & 128 & Deng et al. (2013) \\
\hline
\end{tabular}

$C_{0}$ initial lead concentration, $D$ solid material dosage, $M$ solid material mass

a Langmuir's maximum monolayer adsorption capacity 
Indeed, for an aqueous lead concentration of $200 \mathrm{mg} \mathrm{L}^{-1}$, an adsorbent dosage of $5 \mathrm{~g} \mathrm{~L}^{-1}$ and at $\mathrm{pH}$ 3.6, the removal capacity of BGMW is relatively important compared with a Turkish clinoptilolite (Turan et al. 2005), Ecuadorian heulandites and clinoptilolite (Calvo et al. 2009) and chemically modified Chinese zeolite (Han et al. 2006). Because of the relative scarcity of dynamic assays, this comparison has been extended to batch systems. Even for a given material, the removed pollutant amounts in batch mode are generally more important than those obtained in dynamic mode (Dong et al. 2010) and the removed lead amount by BGMW in CSTR mode is much higher than the related ones determined for a Mexican soil (MartinezVillegas et al. 2004), a Thai Kaolinite (Chantawong et al. 2003), an Iranian dolomite (Irani et al. 2011) and a Turkish illite clay (Ozdes et al. 2011).

\section{Effect of BGMW dosage}

The BMGW dosage is usually considered as an important factor conditioning pollutants removal from aqueous solutions under dynamic conditions. The impact of this parameter on lead removal efficiency has been determined with respect to the experimental conditions presented in section "Effect of the BGMW dosage." The related breakthrough curves indicated that for all the used BGMW dosages, the lead removal process is clearly time dependent (Fig. 3). Indeed, due to the presence of more adsorptive sites and the net increase in the aqueous $\mathrm{pH}$, the higher is the BGMW dosage, the faster is the reaching of equilibrium. This state (minimum of $C / C_{0}$ values) was observed after 1.5, 12, 40 and 62 min for BGMW dosages of 5, 3, 2 and $1 \mathrm{~g} \mathrm{~L}^{-1}$, respectively. This observed kinetic removal process could be explained by the fact that at the beginning, the lead ions were mainly precipitated as lead carbonates. This mechanism is more favored as the BGMW

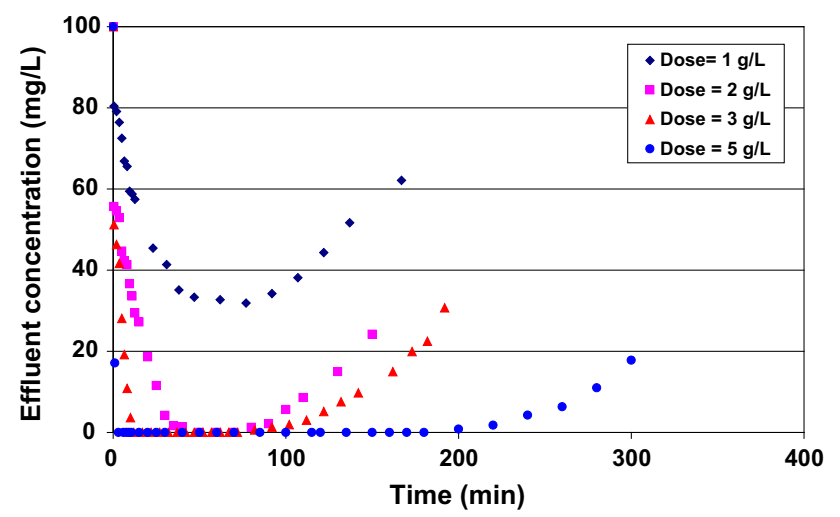

Fig. 3 Effect of BGMW dosage on lead removal from aqueous solutions (influent lead concentration $=100 \mathrm{mg} \mathrm{L}^{-1}$, temperature $=20 \pm 2{ }^{\circ} \mathrm{C}$, flow rate $=20 \mathrm{~mL} \mathrm{~min}^{-1}$ and initial $\mathrm{pH}$ 3.6) dosage increases since the aqueous $\mathrm{pH}$ become more important. The average $\mathrm{pH}$ values at equilibrium were determined to 5.34, 5.98, 6.1 and 6.64 for BGMW dosages of $1,2,3$ and $5 \mathrm{~g} \mathrm{~L}^{-1}$, respectively. Then, lead removal was ensured by both precipitation and adsorption onto active sorption sites. For this last mechanism, after the exterior surface sites saturation, the lead ions enter into the BGMW particles pores and were adsorbed by the interior surface of the particles which result in a slow removal rate (Ozdes et al. 2011; Cechinel et al. 2013).

Except for BGMW dosage of $1 \mathrm{~g} \mathrm{~L}^{-1}$, where the measured minimum lead concentration was about $32 \mathrm{mg} \mathrm{L}^{-1}$ corresponding to a removal efficiency of $68 \%$, BGMW doses of 2, 3 and $5 \mathrm{~g} \mathrm{~L}^{-1}$ have permitted a complete lead removal from the synthetic aqueous solutions. Such trend is mainly attributed to both an increase in adsorption capacity (through an increase in the sorptive surface area and adsorption sites) and the availability of more favorable conditions of lead carbonates precipitation (due to the increase in the aqueous $\mathrm{pH}$ and to the dissolution of more $\mathrm{HCO}_{3}{ }^{-}$ions from BGMW into the aqueous solutions (Godelitsas et al. 2003; Rangel-Porras et al. 2010)). These very attractive lead removal efficiencies, even for relatively low BGMW dosages, could be considered as a promising result and should encourage the use of this kind of wastes as efficient materials for the treatment of real industrial wastewaters rich in heavy metals.

\section{Effect of feeding flow rate}

Figure 4 represents the lead breakthrough curves related to the impact of the feeding flow rate on lead removal from aqueous solutions for the experimental conditions mentioned in section "Effect of the influent feeding flow rate." On the basis of these breakthrough curves, it appears that lead removal efficiency is highly affected by the used flow

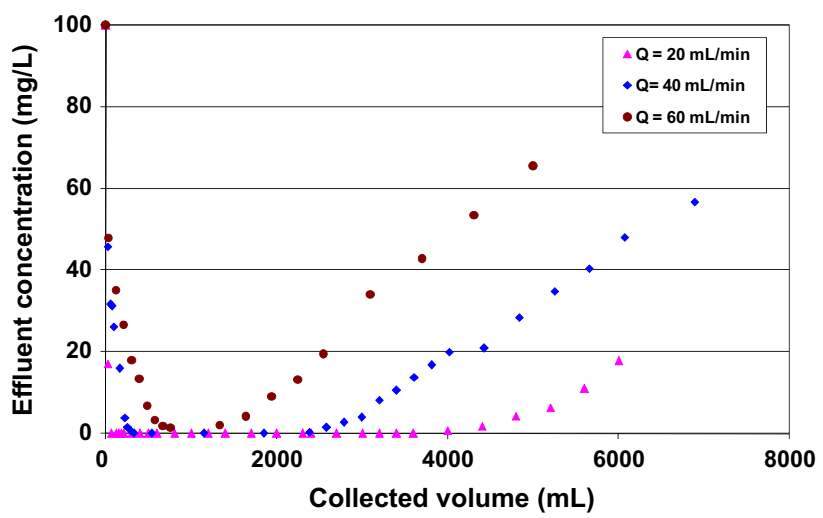

Fig. 4 Effect of influent feeding flow rate on lead removal by BGMW (influent lead concentration $=100 \mathrm{mg} \mathrm{L}^{-1}$, BGMW dosage $=5 \mathrm{~g} \mathrm{~L}^{-1}$, temperature $=20 \pm 2{ }^{\circ} \mathrm{C}$ and initial $\mathrm{pH}$ 3.6) 
rate. Indeed, relatively fast removal kinetic was observed as the flow rate decreases. The equilibrium state, which is characterized by relatively constant or unchanged concentrations at the outlet of the reactor, was obtained after 3 , 8 and $12.5 \mathrm{~min}$ for used flow rates of 20, 40 and

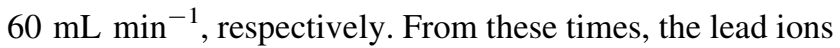
were completely removed from the aqueous solutions for flow rates of 20 and $40 \mathrm{~mL} \mathrm{~min}^{-1}$ and at a percentage of $98.7 \%$ for $60 \mathrm{~mL} \mathrm{~min}{ }^{-1}$. The duration of this equilibrium state corresponds to treated water volumes of $3,540,1,571$ and $760 \mathrm{~mL}$ for flow rates of 20,40 and $60 \mathrm{~mL} \mathrm{~min}{ }^{-1}$, respectively. Thus, for the tested flow rate interval, higher is the contact time between the BGMW and aqueous lead solution, more effective is the lead removal (Fig. 4). This finding is comforted by the research work of Gupta et al. (2011) who studied lead removal by a synthesized composite (alumina-coated multi-wall carbon nanotubes material) using a relatively short bed depth column $(1 \mathrm{~cm})$. For an influent lead concentration of $20 \mathrm{mg} \mathrm{L}^{-1}$, they demonstrated that when the flow rate was decreasing from 5 to $1 \mathrm{~mL} \mathrm{~min}{ }^{-1}$, more favorable adsorption conditions were achieved for lead. The breakthrough curves showed that the effluent solution concentration reached $5 \%$ of its feed concentration at about $80,200,340$ min residence times for 5, 3 and $1 \mathrm{~mL} \min ^{-1}$, respectively (Fig. 4). The same trend has been observed by Han et al. (2006) when they followed lead removal by chemically modified Chinese zeolite in glass column mode.

This finding could be attributed to the fact that for relatively important flow rates, the corresponding residence times were not sufficient to ensure an equilibrium state between BGMW particles and the dissolved lead ions. Moreover, the use of lower flow rates had significantly increased the aqueous $\mathrm{pH}$ of the synthetic solutions which would result in the formation of more amounts of lead carbonates precipitate. However, when the flow rate decreases, the contact time between BGMW and lead ions in the CSTR is longer and consequently intra-particle diffusion becomes effective. Thus, the lead ions have more time to diffuse into the solid particles of BGMW, and better efficiencies removal is obtained. However, at a higher flow rate, probably lower diffusivity of lead ions into BGMW occurs which would result in a relatively rapid saturation of these solid particles. This trend has been observed by Akar et al. (2012) when studying lead removal by a chemically modified biomass in column mode. They found that lead biosorption yield was reduced from about 98.6-83.5 \% when the flow rate was increased from 1.0 to $6.0 \mathrm{~mL} \mathrm{~min}^{-1}$.

The average removed lead amounts were evaluated using Eq. 1, to $67.8,89.9$ and $101.5 \mathrm{mg} \mathrm{g}^{-1}$ for feeding flow rates of 60,40 and $20 \mathrm{~mL} \mathrm{~min}^{-1}$, respectively. This tendency has been also registered by Hasan et al. (2010) when they studied lead removal by a polysulfone immobilized Aeromonas hydrophila biomass using a laboratory column. For a bed height of $19 \mathrm{~cm}$ and an influent lead concentration of $103.6 \mathrm{mg} \mathrm{L}^{-1}$, the removed lead amount decreased from about 54.5 to $49.3 \mathrm{mg} \mathrm{g}^{-1}$ when the applied flow rate increased from 2 to $10 \mathrm{~mL} \mathrm{~min}$.

\section{Effect of initial aqueous $p H$}

The $\mathrm{pH}$ is an important factor for determining the form of the lead species in the aqueous solutions. It influences the strength of the adsorption mechanism of lead ions as it determines the degree and sign of the charge on these ions (Blazquez et al. 2010; Jellali et al. 2011). For example, for an aqueous lead concentration of $100 \mathrm{mg} \mathrm{L}^{-1}$, positively charged lead(II) species are dominant for $\mathrm{pH}$ values lower than 5.3. In case of higher $\mathrm{pH}$ values (pH 6-11), there are several lead species with different charges including $\mathrm{Pb}(\mathrm{OH})^{+}, \mathrm{Pb}_{2}(\mathrm{OH})^{3+}$ and $\mathrm{Pb}(\mathrm{OH})_{2}$. Thus, the removal of lead is possibly accomplished by simultaneous precipitation of $\mathrm{Pb}(\mathrm{OH})_{2}$ and sorption of $\mathrm{Pb}(\mathrm{OH})^{+}$. For $\mathrm{pH}$ values higher than 11 , besides $\mathrm{Pb}(\mathrm{OH})_{2}$, lead ions can be present in the aqueous solutions as anions: $\mathrm{Pb}(\mathrm{OH})_{4}^{2-}$ and $\mathrm{Pb}(\mathrm{OH})_{3}^{-}$ (Blazquez et al. 2010).

The effectiveness of BGMW on lead removal from aqueous solutions versus $\mathrm{pH}$ has been carried out according to the experimental conditions cited in section "Effect of initial aqueous pH." The related breakthrough curves, depicted in Fig. 5, showed that the aqueous $\mathrm{pH}$ has a significant effect on lead removal. Indeed, it appears that lead removal was inhibited at low $\mathrm{pH}$ values. For the lowest tested aqueous $\mathrm{pH}(\mathrm{pH} 2)$, the maximal removal efficiency was evaluated to be about $88 \%$ during only $30 \mathrm{~min}$ time period. However, for initial aqueous $\mathrm{pH}$ values of 3.6 and 5 , the measured lead concentrations at the outlet of the reactor were lower than the detection limit of the apparatus for a relatively long period (177 and $307 \mathrm{~min}$,

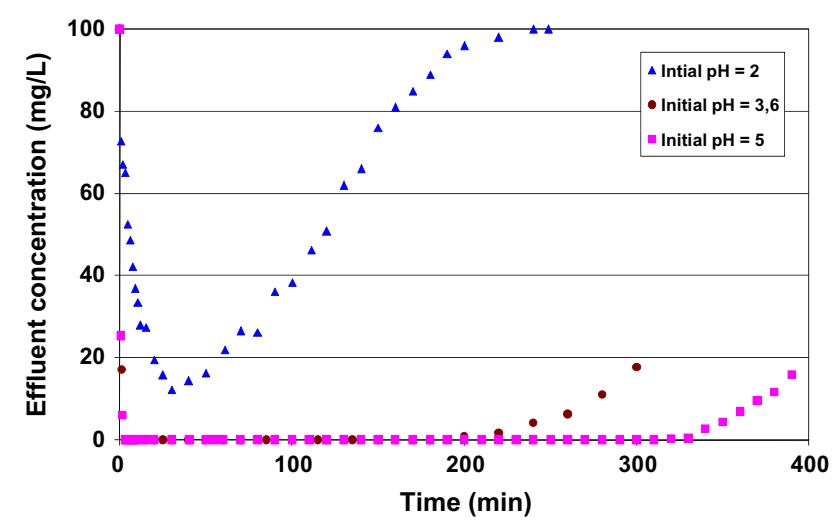

Fig. 5 Effect of initial influent pH on lead removal (influent lead concentration $=100 \mathrm{mg} \mathrm{L}^{-1}$, BGMW dosage $=5 \mathrm{~g} \mathrm{~L} \mathrm{~L}^{-1}$ and temperature $=20 \pm 2{ }^{\circ} \mathrm{C}$ ) 
respectively). This equilibrium state, with minimum $C / C_{0}$ values of the breakthrough curves, corresponds to treated synthetic aqueous volume of about 3,540 and $6,386 \mathrm{~mL}$ for initial aqueous $\mathrm{pH}$ values of 3.6 and 5, respectively. This result was consistent with lead removal studies from synthetic solutions by modified Chinese attapulgite clay (Deng et al. 2013).

The removed lead amounts were determined using Eq. 1 to $34.5 \mathrm{mg} \mathrm{g}^{-1}$ for an initial $\mathrm{pH}$ of 2 . This amount increases to 101.5 and $130.7 \mathrm{mg} \mathrm{g}^{-1}$ represented by increase percentages of 194 and $279 \%$ for aqueous $\mathrm{pH}$ of 3.6 and 5, respectively. This finding is mainly caused by the fact that at lower $\mathrm{pH}$, the concentration of positive charge (protons) increased on the sites of the solid particles surface, which limited the approach of lead ions because of charge-repulsion phenomenon. As aqueous $\mathrm{pH}$ values increase, the charge density on the BGMW surface becomes more negative and the protons concentrations decrease. This behavior will favor the removal of the positively charged lead ions onto the solid particles surface. On the other hand, the aqueous $\mathrm{pH}$ values of the solution in the reactor during the equilibrium phase become more important when increasing the initial $\mathrm{pH}$ solutions. Indeed, these equilibrium $\mathrm{pH}$ values were evaluated to $5.73,6.64$ and 6.68 for initial $\mathrm{pH}$ of 2,3.6 and 5, respectively. This result indicates that the precipitation phenomenon of lead (as lead carbonates) should be more favored as the initial aqueous $\mathrm{pH}$ values increased. This trend has been also pointed out by Rangel-Porras et al. (2010), where they studied lead removal using calcitic materials.

\section{Effect of ions competition}

Generally, several metal ions are ubiquitous in natural waters and industrial effluents, so it is important to study the sorption selectivity of BGMW toward target metal ions when assessing its technical applicability. In this regard, the impact of the presence of other heavy metals on lead removal from the synthetic aqueous solutions has been carried out according to the experimental conditions given in section "Effect of ions competition." The results indicated that maximal lead removal efficiency by BGMW (at equilibrium) has decreased due to the presence of other metals from 100 to $82.5 \%$. The observed decrease in the lead removal in the presence of the other metals could be explained by the adsorption competition between metal ions for the same sorption sites. The removal efficiencies of $\mathrm{Cd}, \mathrm{Zn}$ and $\mathrm{Cu}$ were estimated to $4.9 ; 15.1$ and $41.8 \%$, respectively (Fig. 6). They were relatively lower than the lead one which proves that for real wastewaters rich in mixture of heavy metals, lead ions will be preferentially removed. The same trend has been observed by Calvo et al. (2009) when they studied the removal of $\mathrm{Pb}^{2+}, \mathrm{Cu}^{2+}$,

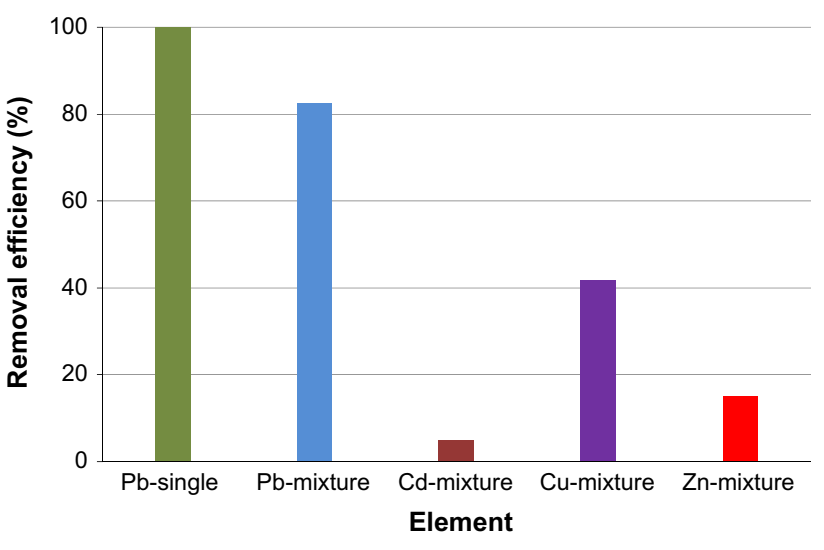

Fig. 6 Effect of the presence of other metals on lead removal $\left(\right.$ BGMW dosage $=5 \mathrm{~g} \mathrm{~L}^{-1}, \mathrm{pH} 3.6$ and temperature $=20 \pm 2{ }^{\circ} \mathrm{C}$ )

$\mathrm{Zn}^{2+}, \mathrm{H}^{+}$and $\mathrm{NH}_{4}{ }^{+}$by natural zeolite tuffs under dynamic mode using laboratory columns. Furthermore, RangelPorras et al. (2010) found that cadmium removal efficiency by three calcitic limestone materials from Mexico was much lower than lead. This, preferentiality to lead in comparison with the other metals, could be attributed to their physicochemical characteristics (size and electronegativity), their availability (the more available metal is better adsorbed onto the sorption sites) and the facility of the formation of the corresponding metal hydroxides complexes (Abdel-Aty et al. 2013). Furthermore, this sorption preference to lead may be also imputed to the fact that its hydration energy is lower than those of the other mentioned heavy metal ions (Rangel-Porras et al. 2010; Depci et al. 2012; Deng et al. 2013). In fact, the cations with the highest (absolute value) free energy of hydration should preferably remain in the solution phase where their hydration requirements may be better satisfied.

\section{CSTRs tests using secondary wastewater}

The CSTR system has been used to study the efficiency of BGMW to remove lead from a real wastewater discharged by a battery manufacture. The main characteristics of this wastewater are presented in Table 1 (see section "Validation with industrial wastewater"). Figure 7 gives the variation of lead concentration at the outlet of the CSTR for BGMW doses of 5,10 and $20 \mathrm{~g} \mathrm{~L}^{-1}$. Because of the relatively low initial aqueous $\mathrm{pH}$ value of the real wastewater (1.1), no significant removal of lead has been observed for a BGMW dose of $5 \mathrm{~g} \mathrm{~L}^{-1}$ since a quasi-constant lead concentration (relatively similar to the influent one) has been measured at the outlet of the reactor. The $\mathrm{pH}$ values of the aqueous samples collected at the outlet of the reactor were globally constants and equal to the initial value (1.1). Increasing the BGMW dose to $10 \mathrm{~g} \mathrm{~L}^{-1}$ has permitted a 


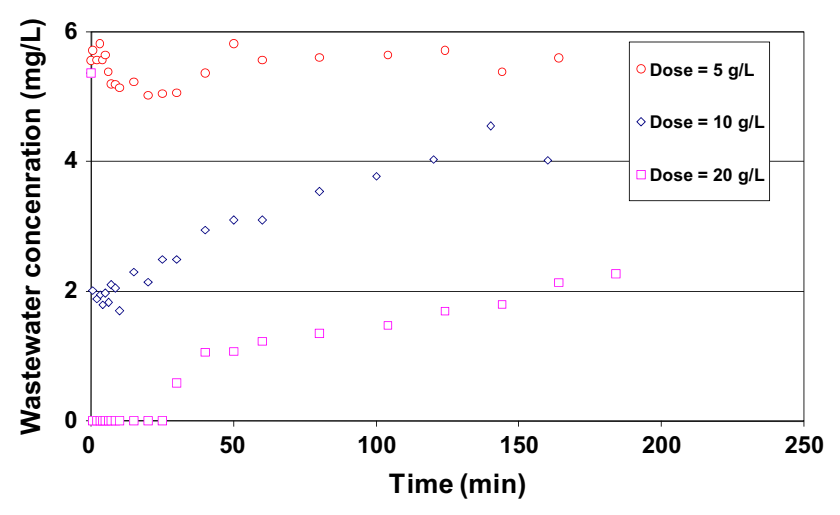

Fig. 7 Effect of BGMW dosage on lead removal from real wastewater (influent lead concentration $=5.4 \mathrm{mg} \mathrm{\textrm {L } ^ { - 1 }}$, temperature $=20 \pm 2{ }^{\circ} \mathrm{C}$, flow rate $=20 \mathrm{~mL} \mathrm{~min}^{-1}$ and initial $\mathrm{pH} 1.1$ )

rapid decrease in the lead concentrations. Indeed, the measured average lead concentration during the period up to $10 \mathrm{~min}$ were evaluated to be about $1.9 \mathrm{mg} \mathrm{L}^{-1}$ corresponding to a removal efficiency of about $64 \%$. This is mainly due to the presence of more adsorption sites since the average effluent $\mathrm{pH}$ has not significantly increased (stabilized to about 1.2). However, a BGMW dose of $20 \mathrm{~g} \mathrm{~L}^{-1}$ has permitted a rapid and complete removal of lead for a time period of $25 \mathrm{~min}$. This finding might be due to the combined effects of the presence of more adsorption sites and lead precipitation since the corresponding measured $\mathrm{pH}$ values during the first 10 min were higher than 6 . After this time, a net decrease in the aqueous $\mathrm{pH}$ values and also the lead removal efficiencies were registered. This dosage is ten times higher than the one required for the synthetic solutions (see section "Effect of BGMW dosage"). This finding could be imputed to the very lower $\mathrm{pH}$ and the presence of relatively higher ions contents in the real wastewater.

Lead removal mechanisms exploration

\section{Distinction between adsorption and precipitation}

Lead removal from the aqueous solutions might occur by precipitation as lead carbonates or lead hydroxides complexes and also by adsorption onto the active sites of the surface of the BGMW particles. The precipitation of lead is instantaneous and very dependent on the aqueous $\mathrm{pH}$ values and the solutions contents of $\mathrm{OH}^{-}, \mathrm{HCO}_{3}{ }^{-}$and $\mathrm{Pb}^{2+}$. However, the adsorption phenomenon generally occurs in three steps: (1) transfer of lead from the aqueous solution to the sites of the adsorbent (boundary layer diffusion), (2) chemical complexation/ion exchange at the active sites of the adsorbent surface and (3) intra-particle diffusion of lead into the interior pores of the BGMW particles (Weber and Morris 1963).
In order to differentiate between these mechanisms cited above, specific batch assays have been carried out. In the first set of assays, aqueous lead at an initial concentration of $100 \mathrm{mg} \mathrm{L}^{-1}$ and initial $\mathrm{pH}$ of 3.6 was put in contact for $1 \mathrm{~h}$ with $5 \mathrm{~g} \mathrm{~L}^{-1}$ of BGMW. Thus, the lead removal was imputed to both adsorption and precipitation mechanisms. While, for the second set of experiments, the same lead concentration was introduced in contact for $1 \mathrm{~h}$ with a filtrate aqueous solution (using a $0.45 \mu \mathrm{m}$ paper filter). This filtrate solution results from the shaking of $5 \mathrm{~g} \mathrm{~L}^{-1}$ BGMW in distilled water at the same initial $\mathrm{pH}$ (3.6). For this case, lead removal is exclusively due to precipitation. The experimental results show that in the first set of assays, adsorption and precipitation mechanisms succeed to completely remove lead from the aqueous solution. However, for the second type of assays, where only lead mechanism precipitation is present, the lead concentration has decreased from 100 to $42.97 \mathrm{mg} \mathrm{L}^{-1}$, which corresponds to an average efficiency of $57 \%$. Therefore, under the experimental conditions cited above, lead removal from the synthetic aqueous solutions occurs by both precipitation and adsorption with an average contribution of about 57 and $43 \%$, respectively.

\section{EDS analysis results}

EDS spectra of BGMW samples before and after lead ions removal are shown in Fig. 8a, b. The EDS spectra of BGMW exhibit peaks for $\mathrm{Ca}, \mathrm{C}, \mathrm{O}$ and $\mathrm{Mg}$, which are their main basic constituents (Fig. 8a). For the BGMW loaded lead ions sample, there are new peaks appearing in the EDAX spectrum, which are attributed to lead element (Fig. 8b). Therefore, the presence of a strong peak at $2.34 \mathrm{keV}$ and small peaks at other locations in the EDS spectra provided an important evidence for lead adsorption on BGMW. On the other hand, EDS analysis of the solid phase formed as a consequence of lead precipitation (second set of assays: see section "Distinction between adsorption and precipitation") indicates that it is mainly formed by $\mathrm{Pb}, \mathrm{O}$ and $\mathrm{C}$ (Fig. 8c).

\section{XRD analysis results}

$\mathrm{XRD}$ analysis has been done on the precipitated solid phase in order to determine the nature of this phase. The X-ray diffraction pattern (Fig. 9) indicates that this solid phase is formed by both cerussite $\left(\mathrm{PbCO}_{3}\right)$ and hydrocerussite $\left(\mathrm{Pb}_{3}(\mathrm{CO} 3)_{2} \mathrm{OH}\right)_{2}$. This result is in concordance with the finding of Rangel-Porras et al. (2010), where they studied lead removal by calcitic materials. On the basis of the MINEQL software, hydrocerussite begins to appear at $\mathrm{pH}$ 5.0 and is the predominant species in the $\mathrm{pH}$ range between 
Fig. 8 EDS analysis results of raw BGMW (a), Pb-loaded BGMW (b) and lead precipitate solid phase (c)

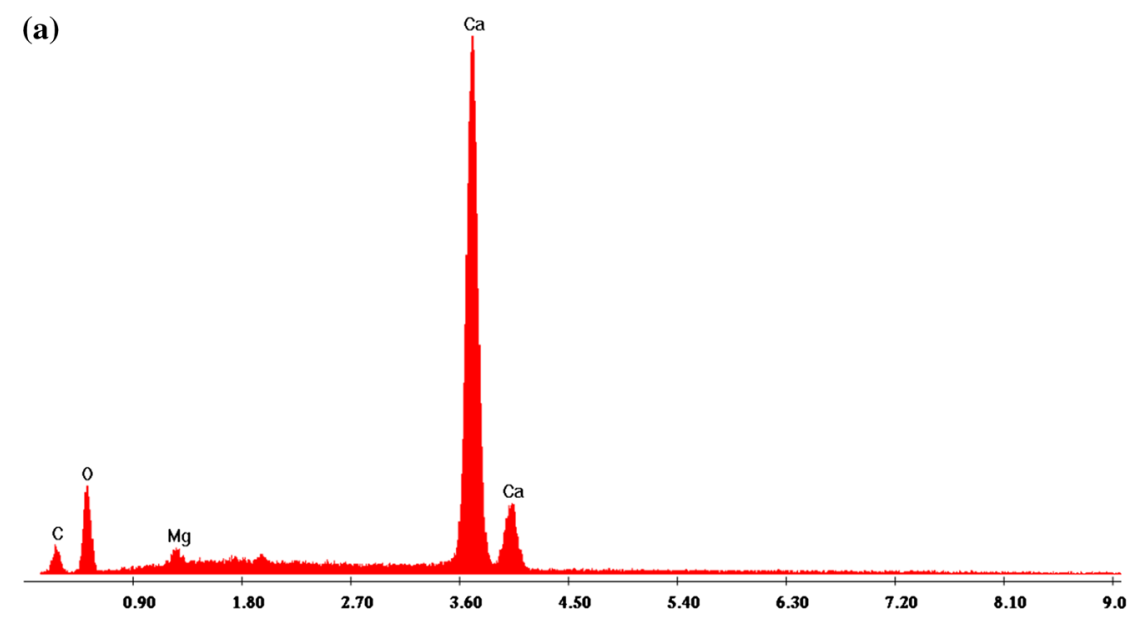

(b)

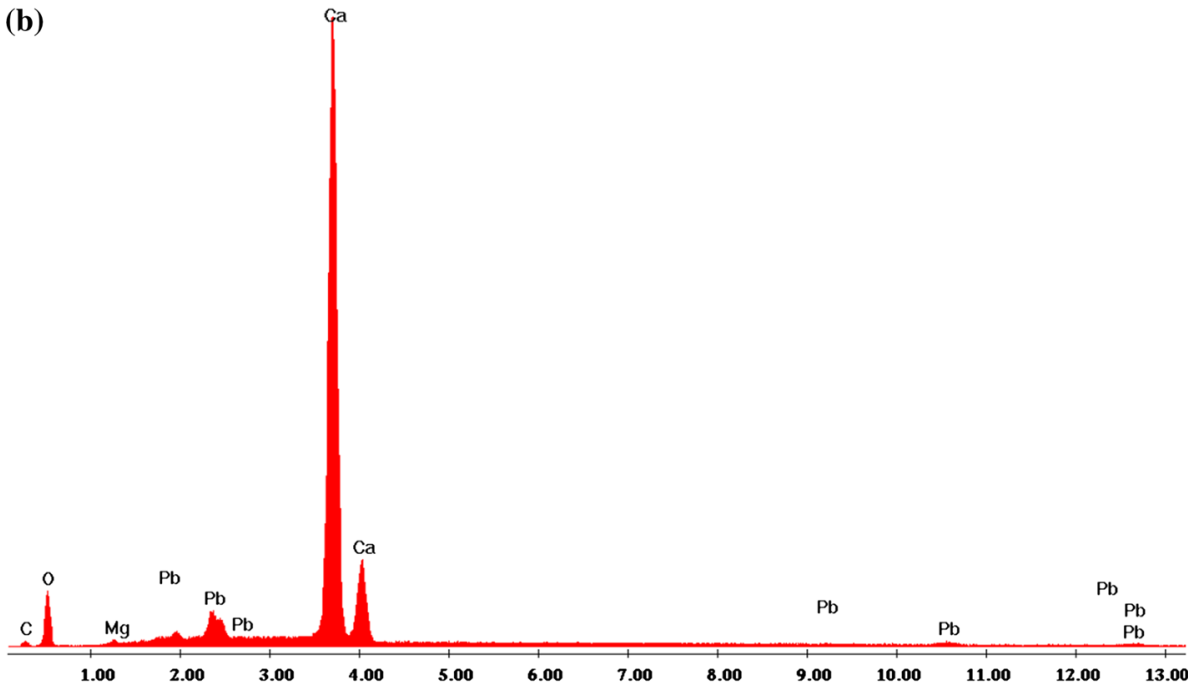

(c)

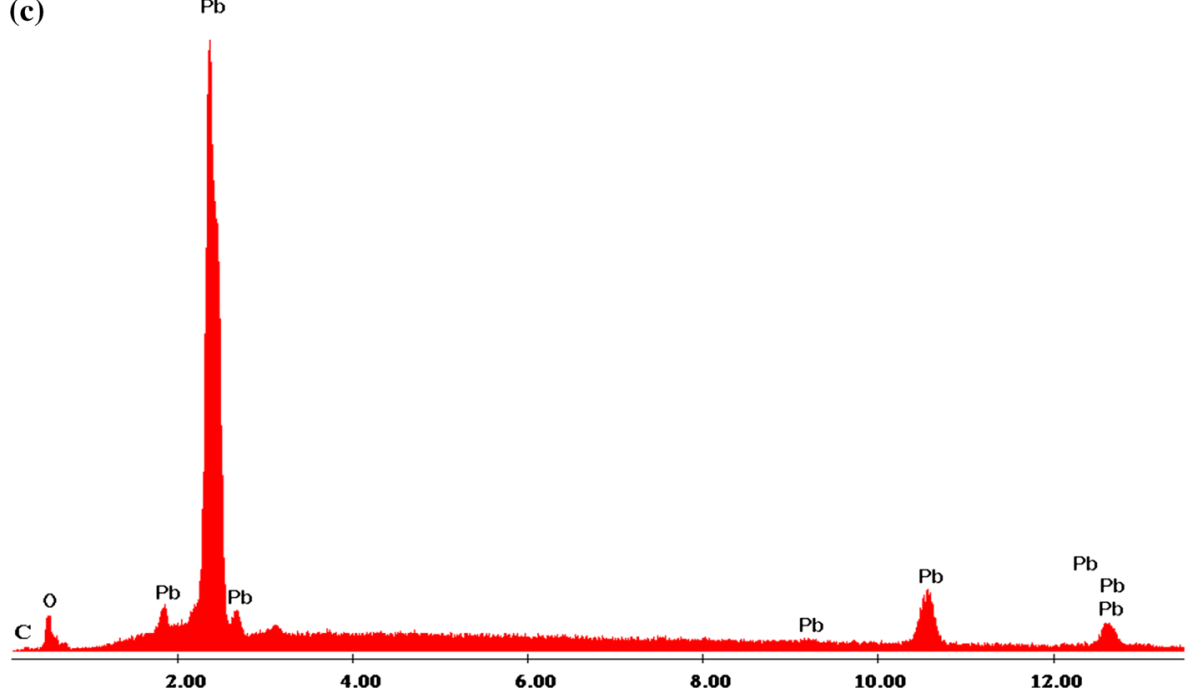

5.5 and 7.5. However, cerussite could appear at lower $\mathrm{pH}$ (4.5), and it is predominating in the wide $\mathrm{pH}$ range above 8.0.
When BGMW particles are suspended in water, the main ions present in the system as a function of aqueous $\mathrm{pH}$ will be the following: $\mathrm{Ca}^{2+}, \mathrm{HCO}_{3}{ }^{-}, \mathrm{CaHCO}_{3}{ }^{+}$, 
Fig. 9 XRD analyses of raw BGMW (a), formed precipitate after contact between lead ions and filtered BGMW solution (b) (1: calcite, 2: dolomite, 3: cerussite and 4: hydrocerussite)

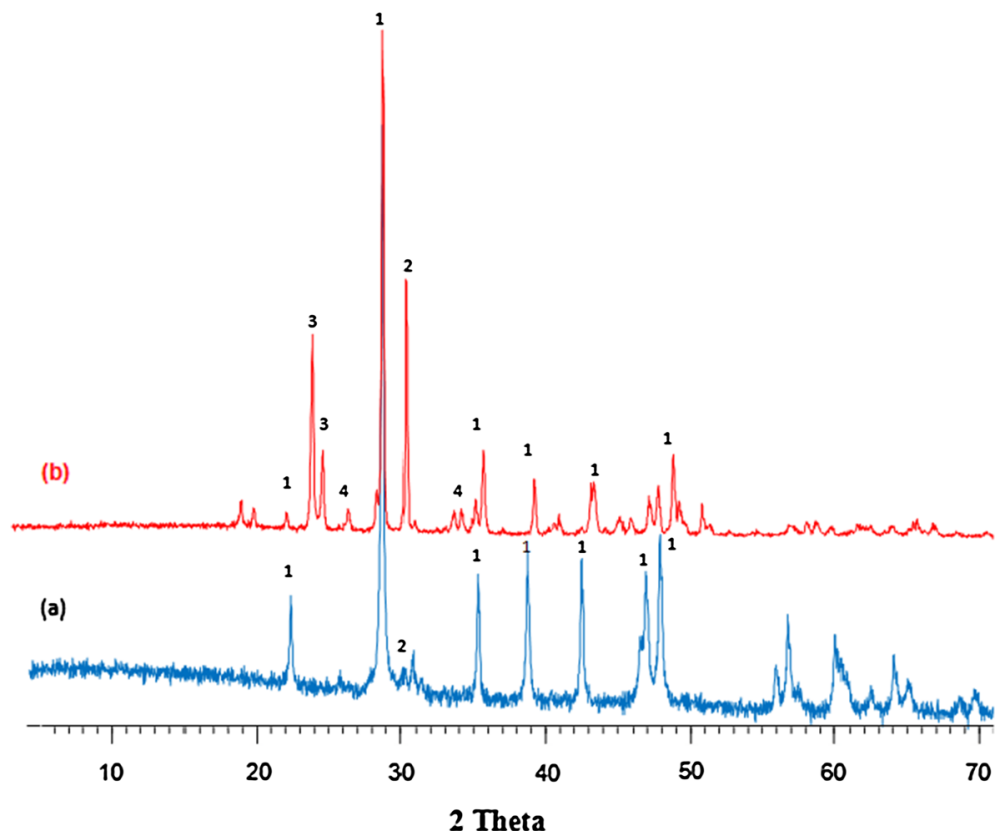

$\mathrm{CaHO}^{+}, \mathrm{H}^{+}$and $\mathrm{OH}^{-}$. In presence of lead, the main species were $\mathrm{Pb}^{2+}, \mathrm{Pb}\left(\mathrm{CO}_{3}\right)^{+}, \mathrm{Pb}\left(\mathrm{NO}_{3}\right)^{+}, \mathrm{Pb}\left(\mathrm{CO}_{3}\right)$ aq and $\mathrm{Pb}\left(\mathrm{CO}_{3}\right)_{2}^{2-}$. Therefore, lead removal can occur through precipitation in the form of $\mathrm{PbCO}_{3}$ and $\mathrm{Pb}(\mathrm{CO} 3)_{2}(\mathrm{OH})_{2}$ and their deposition at the BGMW surfaces as follows (Zhu 2002):

$$
\begin{aligned}
& \equiv \mathrm{CaCO}_{3}^{0}+\mathrm{Pb}^{2+}+\mathrm{HCO}_{3}^{-} \leftrightarrow \mathrm{CaCO}_{3}(\mathrm{~s})+ \\
& \equiv \mathrm{PbCO}_{3}^{0}+\mathrm{H}^{+} \\
& \equiv \mathrm{PbCO}_{3}^{0}+\mathrm{Pb}^{2+}+\mathrm{HCO}_{3}^{-} \leftrightarrow \mathrm{PbCO}_{3}(\mathrm{~s})+ \\
& \equiv \mathrm{PbCO}_{3}^{0}+\mathrm{H}^{+} \\
& \equiv \mathrm{CaCO}_{3}^{0}+3 \mathrm{~Pb}^{2+}+2 \mathrm{HCO}_{3}^{-}+2 \mathrm{OH}^{-} \leftrightarrow \mathrm{CaCO}_{3}(\mathrm{~s}) \\
& +\equiv\left(\mathrm{Pb}_{3}\left(\mathrm{CO}_{3}\right)_{2}(\mathrm{OH})_{2}\right)^{0}+2 \mathrm{H}^{+} \\
& \equiv\left(\mathrm{Pb}\left(\mathrm{CO}_{3}\right)_{2}(\mathrm{OH})_{2}\right)^{0}+3 \mathrm{~Pb}^{2+}+2 \mathrm{HCO}_{3}^{-}+2 \mathrm{OH}^{-} \\
& \leftrightarrow \mathrm{Pb}_{3}\left(\mathrm{CO}_{3}\right)_{2}(\mathrm{OH})_{2}(s)+\equiv\left(\mathrm{Pb}_{3} \mathrm{CO}_{3}(\mathrm{OH})_{2}\right)^{0}+2 \mathrm{H}^{+}
\end{aligned}
$$

On the other hand, it is worth to mention that for all assays' results mentioned above, the measured $\mathrm{pH}$ values at the outlet of the CSTR were significantly lower than the $\mathrm{pH}_{\mathrm{PZC}}$ of the used BGMW, which has been evaluated to 8.11. Thus, the removal of lead ions has caused a net decrease in the aqueous $\mathrm{pH}$ values. This $\mathrm{pH}$ drop might be due to both $\mathrm{OH}^{-}$ions consumption for lead carbonates (cerussite: $\mathrm{PbCO}_{3}$ and hydrocerussite $\left(\mathrm{Pb}_{3}\left(\mathrm{CO}_{3}\right)_{2}(\mathrm{OH})_{2}\right)$ formation and also to the liberation of $\mathrm{H}^{+}$ions from the solid surface into the solution as a result of exchange with lead ions. As assumed by Dong et al. (2010) and Fan et al.
(2009), when studying lead removal under static mode by hydroxyapatite/magnetite composite adsorbent and Chinese natural palygorskite, respectively, lead removal by BGMW particles could be ensured through the formation of inner-sphere complexes as follows:

$$
\begin{aligned}
& \mathrm{BGMW}-\mathrm{OH}+\mathrm{Pb}^{2+} \rightarrow \mathrm{BGMW}-\mathrm{O}-\mathrm{Pb}^{+}+\mathrm{H}^{+} \\
& 2 \mathrm{BGMW}-\mathrm{OH}+\mathrm{Pb}^{2+} \rightarrow(\mathrm{BGMW}-\mathrm{O})_{2}-\mathrm{Pb}+2 \mathrm{H}^{+}
\end{aligned}
$$

Lead removal from the aqueous solutions could occur also through cation-exchange mechanism with calcium ions:

$\mathrm{Pb}^{2+}$ BGMW-Ca $\rightarrow \mathrm{Ca}^{2+}+$ BGMW-Pb

This mechanism is also referred as outer-sphere complexation and does not involve formation of bonds between metal ions and the BGMW surface.

\section{Conclusion}

In the present work, Bianco Gioia marble wastes (BGMW), abundant and renewable wastes, have been tested under dynamic conditions as a low-cost material for lead removal from synthetic solutions and real wastewater. The experimental results confirm that BGMW can be considered as attractive and alternative materials for lead removal from synthetic aqueous solutions compared with various other materials. Indeed, even for relatively low doses $\left(5 \mathrm{~g} \mathrm{~L}^{-1}\right)$, 
efficient removal of lead has been performed for a wide $\mathrm{pH}$ and aqueous concentrations ranges. BGMW application for lead removal from real wastewater showed that due to its very low $\mathrm{pH}(\mathrm{pH} 1.1)$, a BGMW dose of $20 \mathrm{~g} \mathrm{~L}^{-1}$ was necessary to ensure a complete removal of lead. The main mechanisms involved in the lead removal were precipitation as cerussite and hydrocerussite, and adsorption through cation exchange and complexation.

The tested CSTR system could be up scaled and integrated in existing industrial wastewaters treatment plants with the added benefit of reducing derogatory environmental impacts of wastewaters discharge in water bodies.

Acknowledgments This research work has been carried out in the framework of a Tunisian national project. Financial support of this work by the Tunisian Ministry of Higher Education and Scientific Research is gratefully acknowledged. Authors are also grateful to Dr. S. Jomaa, Dr. A. Chkirbene, Dr. M. Kefi and Dr. H. Hamdi for checking English phrasing of the manuscript.

\section{References}

Abdel-Aty AM, Ammar NS, Abdel-Ghafar HH, Ali RK (2013) Biosorption of cadmium and lead from aqueous solution by fresh water alga Anabaena sphaerica biomass. J Adv Res 4:367-374

Akar ST, Arslan D, Alp T (2012) Ammonium pyrrolidine dithiocarbamate anchored Symphoricarpus albus biomass for lead(II) removal: batch and column biosorption study. J Hazard Mater 227-228:107-117

Aukour FJ, Al-Qinna MI (2008) Marble production and environmental constrains: case study from Zarqa Governorate, Jordan. Jordan J Earth Environ Sci 1:11-21

Banerjee D (2014) Acid drainage potential from coal mine wastes: environmental assessment through static and kinetic tests. Int $\mathbf{J}$ Environ Sci Technol 11:1365-1378

Blazquez G, Calero M, Hernáinz F, Tenorio G, Martin-Lara MA (2010) Equilibrium biosorption of lead(II) from aqueous solutions by solid waste from olive-oil production. Chem Eng J 160:615-622

Bourliva A, Michailidis K, Sikalidis C, Filippidis A, Betsiou M (2013) Lead removal from aqueous solutions by natural Greek bentonites. Clay Miner 48:771-787

Calero M, Ronda A, Martın-Lara MA, Perez A, Blazquez G (2013) Chemical activation of olive tree pruning to remove lead(II) in batch system: factorial design for process optimization. Biomass Bioenergy 58:322-332

Calvo B, Canoira L, Morante F, Martinez-Bedia JM, Vinagre C, Garcia-Gonzalez J, Elsen J, Alcantara R (2009) Continuous elimination of $\mathrm{Pb}^{2+}, \mathrm{Cu}^{2+}, \mathrm{Zn}^{2+}, \mathrm{H}^{+}$and $\mathrm{NH}_{4}^{+}$from acidic waters by ionic exchange on natural zeolites. J Hazard Mater 166:619-627

Cechinel MAP, de Souza SMAGU, de Souza AAU (2013) Study of lead(II) adsorption onto activated carbon originating from cow bone. J Clean Prod 65:342-349

Chada VGR, Hausner DB, Strongin DR, Rouff AA, Reeder RJ (2005) Divalent $\mathrm{Cd}$ and $\mathrm{Pb}$ uptake on calcite 10.14 cleavage faces: an XPS and AFM study. J Colloid Interface Sci 288:350-360

Chakraborty A, Deva D, Sharma A, Verma N (2011) Adsorbents based on carbon microfibers and carbon nanofibers for the removal of phenol and lead from water. J Colloid Interface Sci 359:228-239
Chantawong V, Harvey NW, Bashkin VN (2003) Comparison of heavy metal adsorptions by Thai kaolin and ball clay. Water Air Soil Pollut 148:111-125

Cruz-Olivares J, Pérez-Alonso C, Barrera-Diaz C, López G, BalderasHernandez P (2010) Inside the removal of lead(II) from aqueous solutions by de-oiled allspice husk in batch and continuous processes. J Hazard Mater 181:1095-1101

Deng Y, Gao Z, Liu B, Hu X, Wei Z, Sun C (2013) Selective removal of lead from aqueous solutions by ethylenediamine-modified attapulgite. Chem Eng J 223:91-98

Depci T, Kul AR, Onal Y (2012) Competitive adsorption of lead and zinc from aqueous solution on activated carbon prepared from Van apple pulp: study in single- and multi-solute systems. Chem Eng J 200-202:224-236

Dong L, Zhu Z, Qiu Y, Zhao J (2010) Removal of lead from aqueous solution by hydroxyapatite/magnetite composite adsorbent. Chem Eng J 165:827-834

Fan Q, Li Z, Zhao H, Jia Z, Xu J, Wu W (2009) Adsorption of Pb(II) on palygorskite from aqueous solution: effects of $\mathrm{pH}$, ionic, strength and temperature. Appl Clay Sci 45:111-116

Ghazy SE, Gad AHM (2010) Lead separation by sorption onto powdered marble waste. Arab J Chem. doi:10.1016/j.arabjc. 2010.10 .031

Ghazy SE, Ragab AH (2007) Removal of lead from water samples by sorption onto powdered limestone. Sep Sci Technol 42:653-667

Godelitsas A, Astilleros JM, Hallam K, Harissopoulos S, Putnis A (2003) Interaction of calcium carbonates with lead in aqueous solution. Environ Sci Technol 37:3351-3360

Gupta VK, Agarwal S, Saleh TA (2011) Synthesis and characterization of alumina-coated carbon nanotubes and their application for lead removal. J Hazard Mater 185:17-23

Han R, Zou W, Li H, Li Y, Shi J (2006) Copper(II) and lead(II) removal from aqueous solution in fixed-bed columns by manganese oxide coated zeolite. J Hazard Mater B137:934-942

Hasan SH, Srivastava P, Talat M (2010) Biosorption of lead using immobilized Aeromonas hydrophila biomass in up flow column system: factorial design for process optimization. J Hazard Mater 177:312-322

Irani M, Amjadi M, Mousavian MA (2011) Comparative study of lead sorption onto natural perlite, dolomite and diatomite. Chem Eng J 178:317-323

Jaouadi S, Wahab MA, Anane M, Bousselmi L, Jellali S (2014a) Powdered marble wastes reuse as a low cost material for phosphorus removal from aqueous solutions under dynamic conditions. Desalin Water Treat 5:1716-1724

Jaouadi S, Mlayah A, Jellali S (2014b) Phosphates removal from aqueous solutions by marble wastes under static conditions. Desalin Water Treat 5:1705-1715

Jellali S, Diamantopoulos E, Kallali H, Bennaceur S, Anane M, Jedidi N (2010) Dynamic sorption of ammonium by sandy soil in fixed bed columns: evaluation of equilibrium and non-equilibrium transport processes. J Environ Manag 91:897-905

Jellali S, Wahab MA, Anane M, Riahi K, Jedidi N (2011) Biosorption characteristics of ammonium from aqueous solutions onto Posidonia oceanica (L.) fibers. Desalination 270:40-49

Martinez-Villegas N, Flores-Velez LM, Domínguez O (2004) Sorption of lead in soil as a function of $\mathrm{pH}$ : a study case in Mexico. Chemosphere 57:1537-1542

McQuarrie C, McQuarrie D, Rock PA (2000) Chimie générale, 3rd edn. De BoeckSupérieur

Mlayah A, da Silva EAE, Rocha F, Ben Hamza C, Charef A, Noronha F (2009) The OuedMellegue: mining activity, stream sediment and dispersion of base metals in natural environments, Northwestern Tunisia. J Geochem Explor 102:27-36

Momcilovic M, Purenovic M, Bojic A, Zarubica A, Randelovic M (2011) Removal of lead(II) ions from aqueous solutions by 
adsorption onto pine cone activated carbon. Desalination 276(1-3):53-59

Ozdes D, Duran C, Senturk HB (2011) Adsorptive removal of Cd(II) and $\mathrm{Pb}(\mathrm{II})$ ions from aqueous solutions by using Turkish illitic clay. J Environ Manag 92:3082-3090

Rangel-Porras G, García-Magno JB, González-Munoz MP (2010) Lead and cadmium immobilization on calcitic limestone materials. Desalination 262:1-10

Sheikhhosseini A, Shirvani M, Shariatmadari H (2013) Competitive sorption of nickel, cadmium, zinc and copper on palygorskite and sepiolite silicate clay minerals. Geoderma 192:249-253

Singh J, Ali A, Prakash V (2014) Removal of lead (II) from synthetic and batteries wastewater using agricultural residues in batch/ column mode. Int J Environ Sci Technol 11:1759-1770

Turan M, Mart U, Yuksel B, Celik MS (2005) Lead removal in fixedbed columns by zeolite and sepiolite. Chemosphere 60:1487-1492
Venalainen SH (2012) Sorption of lead by phlogopite-rich mine tailings. Appl Geochem 27:1593-1599

Weber WJ, Morris JC (1963) Kinetics of adsorption on carbon from solution. J Sanit Eng Div Am Soc Civ Eng 89:31-60

Wei X, Viadero RC, Bhojappa S (2008) Phosphorus removal by acid mine drainage sludge from secondary effluents of municipal wastewater treatment plants. Water Res 32:3275-3284

Zamani AA, Shokri R, Yaftian MR, Parizanganeh AH (2013) Adsorption of lead, zinc and cadmium ions from contaminated water onto Peganum harmala seeds as biosorbent. Int J Environ Sci Technol 10:93-102

Zhu C (2002) Estimation of surface precipitation constants for sorption of divalent metals onto hydrous ferric oxide and calcite. Chem Geol 188:23-32 